Utah State University

DigitalCommons@USU

$9-1-2016$

\title{
Systems Modeling to Improve the Hydro-Ecological Performance of Diked Wetlands
}

Omar Alminagorta

Utah State University

David E. Rosenberg

Utah State University

Karin M. Kettenring

Utah State University

Follow this and additional works at: https://digitalcommons.usu.edu/water_pubs

Part of the Water Resource Management Commons

\section{Recommended Citation}

Alminagorta, Omar; Rosenberg, David E.; and Kettenring, Karin M., "Systems Modeling to Improve the Hydro-Ecological Performance of Diked Wetlands" (2016). Publications. Paper 18.

https://digitalcommons.usu.edu/water_pubs/18

This Article is brought to you for free and open access by the Utah Water Research Laboratory at DigitalCommons@USU. It has been accepted for inclusion in Publications by an authorized administrator of DigitalCommons@USU. For more information, please contact digitalcommons@usu.edu.

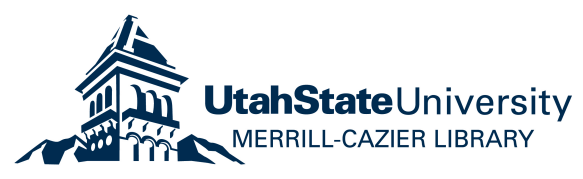




\section{Water Resources Research}

\section{RESEARCH ARTICLE Systems modeling to improve the hydro-ecological 10.1002/2015WR018105}

Key Points:

- A wetland systems management model recommends coordinated water allocation and invasive vegetation control to improve bird habitat

- More dynamic water level management and earlier invasive species control increase suitable habitat area for migratory birds

- Model overestimates suitable habitat area when it omits invasive vegetation and its control

Supporting Information: - Supporting Information S1

Correspondence to:

O. Alminagorta,

o.alminagorta@aggiemail.usu.edu

Citation:

Alminagorta, O., D. E. Rosenberg, and K. M. Kettenring (2016), Systems modeling to improve the hydroecological performance of diked wetlands, Water Resour. Res., 52, doi:10.1002/2015WR018105.

Received 12 SEP 2015 Accepted 29 AUG 2016 Accepted article online 1 SEP 2016

\author{
Omar Alminagorta1, David E. Rosenberg², and Karin M. Kettenring ${ }^{3}$ \\ ${ }^{1}$ Utah Water Research Laboratory, Utah State University, Logan, Utah, USA, ${ }^{2}$ Department of Civil and Environmental \\ Engineering and Utah Water Research Laboratory, Utah State University, Logan, Utah, USA, ${ }^{3}$ Ecology Center and \\ Department of Watershed Sciences, Utah State University, Logan, Utah, USA
}

\begin{abstract}
Water scarcity and invasive vegetation threaten arid-region wetlands and wetland managers seek ways to enhance wetland ecosystem services with limited water, labor, and financial resources. While prior systems modeling efforts have focused on water management to improve flow-based ecosystem and habitat objectives, here we consider water allocation and invasive vegetation management that jointly target the concurrent hydrologic and vegetation habitat needs of priority wetland bird species. We formulate a composite weighted usable area for wetlands $(W U)$ objective function that represents the wetland surface area that provides suitable water level and vegetation cover conditions for priority bird species. Maximizing the $W U$ is subject to constraints such as water balance, hydraulic infrastructure capacity, invasive vegetation growth and control, and a limited financial budget to control vegetation. We apply the model at the Bear River Migratory Bird Refuge on the Great Salt Lake, Utah, compare model-recommended management actions to past Refuge water and vegetation control activities, and find that managers can almost double the area of suitable habitat by more dynamically managing water levels and managing invasive vegetation in August at the beginning of the window for control operations. Scenario and sensitivity analyses show the importance to jointly consider hydrology and vegetation system components rather than only the hydrological component.
\end{abstract}

\section{Introduction}

Wetland ecosystems provide critical habitat for wildlife, water quality improvement, and flood mitigation. Yet in arid regions of the world, these ecosystem services are threatened by water scarcity and invasive species [Downard and Endter-Wada, 2013; Euliss et al., 2008; Zedler and Kercher, 2004; Zedler and Kercher, 2005]. The timing, duration, and level of flooding drive many aspects of wetland structure and function [Mitsch and Gosselink, 2007], and together with wetland vegetation, determine the suitability of wetlands for wildlife habitat.

It is often difficult, however, to manage wetland vegetation and hydrology together to enhance ecosystem services [Euliss et al., 2008]. This difficulty arises because the two activities are often undertaken independently of one-another. For example, managers often manipulate the hydrologic regime as a proxy to alter wetland species biology such as reproduction, growth, and survival [Batzer and Sharitz, 2014; Mitsch and Gosselink, 2007]. Water-level changes help maintain wetland biodiversity [Zedler and Kercher, 2005] including to provide habitat for bird communities [Kaminski et al., 2006; Ma et al., 2010]. In contrast, managers control invasive vegetation such as Phragmites australis (common reed, hereafter Phragmites) to directly alter wetland plant community composition [Zedler and Kercher 2004]. Phragmites distribution and abundance has increased dramatically in North America over the past 150 years [Kettenring et al., 2012a; Saltonstall, 2002] and is a serious problem for wetland managers, in part, because it outcompetes other plant species considered to be more important as food or cover for wildlife [Hazelton et al., 2014; Kettenring et al., 2012a]. Phragmites also reduces species diversity by limiting available nesting habitat and food quality for birds [Chambers et al., 1999; Zedler and Kercher, 2004]. Thus, Phragmites control - applying herbicides followed by burning or mowing - can improve habitat quality [Ailstock et al., 2001; Hazelton et al., 2014]. At the same time, control activities require time, staff, and financial resources that in many cases are limited [Kettenring and Adams, 2011] and must be coordinated with water management actions [Ma et al., 2010]. Thus, managers often want to know where, when, and how to apply scarce water, labor, and financial resources to improve wetland habitat [Downard and Endter-Wada, 2013]. 
Systems optimization models can help connect these hydrological, ecological, management, and other system components and show how to allocate scarce resources to improve one or multiple management objectives [Hof and Bevers, 2002; Loucks et al., 2005]. When included, environmental and ecological system model components are often specified as static constraints such that water allocations must obey a minimum in-stream flow value to guarantee fish survival [Draper et al., 2003; Vogel et al., 2007]. A small but growing literature is moving beyond constraint methods to define, embed, and solve for one or multiple ecological objectives in a systems model. For example, a multiobjective optimization model selected the magnitude and frequency of stream flows that maximize fish population under water availability constraints [Cardwell et al., 1996]. A mixed integer model recommended water level and salinity management strategies to maximize avian abundance within fixed basins in San Francisco Bay tidal areas [Stralberg et al., 2009]. A nonlinear integer programming model recommended investments in flow control structures to minimize changes of the natural flow regime in the Murray River, Australia [Higgins et al., 2011]. Szemis et al. [2014] used ant colony optimization to identify environmental flows in the Murray basin that maximize ecological scores for indicator species in wetland and floodplain areas. And in the Connecticut River basin, Steinschneider et al. [2013] used penalty-based linear programming to minimize the departure of reservoir storage levels, releases, and instream flows from target values established to generate hydropower, supply water, and maintain aquatic fish and invertebrate habitat. These systems modeling efforts span diverse aquatic, floodplain, and wetland ecosystems and species, but only used water flow, water level, or a related flow regime attribute as the time-varying, managed resource to influence the ecological objective function and desired outcome. Yet in these and other systems, ecological outcomes depend both on the abiotic factor water and biotic factors such as plant communities that vary through time and in response to managers' control actions.

In this study, we include water levels and wetland vegetation as responsive system components in an optimization model for diked wetlands that simultaneously identifies water allocation and invasive vegetation control actions that maximize a composite weighted usable area for wetlands (WU) objective. This WU objective represents the wetland surface area that provides suitable water levels and vegetation cover conditions for priority bird species. Suitability explicitly considers spatially varying water depths and the associated micro-habitats created by a particular water level within a diked unit. Maximization of $W U$ is subject to constraints such as water availability and water balance, hydraulic infrastructure capacity, invasive vegetation growth, and a limited financial budget to control vegetation. We apply the model at the Bear River Migratory Bird Refuge, Utah (hereafter, the Refuge), which is located on the northeast shore of the Great Salt Lake, Utah and managed by the U.S. Fish and Wildlife Service to provide feeding, resting, and breeding grounds for several globally significant populations of migratory birds. We compare model-recommended water and vegetation management actions to managers' historical activities to suggest strategies to improve migratory bird habitat. Scenario and sensitivity analyses show the importance to jointly consider hydrology and invasive vegetation components rather than only the hydrological component. The work is part of a 7 year collaboration with Refuge managers and also demonstrates a participatory approach to address long-standing challenges to formulate and populate systems models with tractable objective functions, constraints, and data to aid ecosystem management.

\section{Study Area}

The Bear River Migratory Bird Refuge, Utah, lies at the terminus of the Bear River on the northeast corner of the Great Salt Lake (Figure 1), covers $156.3 \mathrm{~km}^{2}$, and is divided into 25 managed wetland units that are separated by dikes. In diked wetlands such as at the Refuge, managers can regulate water through canals, gates, and weirs and manipulate vegetation through burning, mowing, herbicide application, and grazing to maintain and improve bird habitat.

The Refuge has seen wide variability in flows (early 1980s floods compared to recent droughts) and will see further flow reductions if Bear River water is transferred out of the basin to support urban growth on the Wasatch Front, Utah [Anderson et al., 2004; Wurtsbaugh et al., 2016]. Currently, Refuge managers use gates and weirs to fill wetland units in winter and spring and hold water at constant levels for as long as possible through the summer and fall [Downard et al., 2014]. However, this strategy can be difficult to implement in summer months because the Refuge holds a junior water right and more senior Bear River agricultural users 


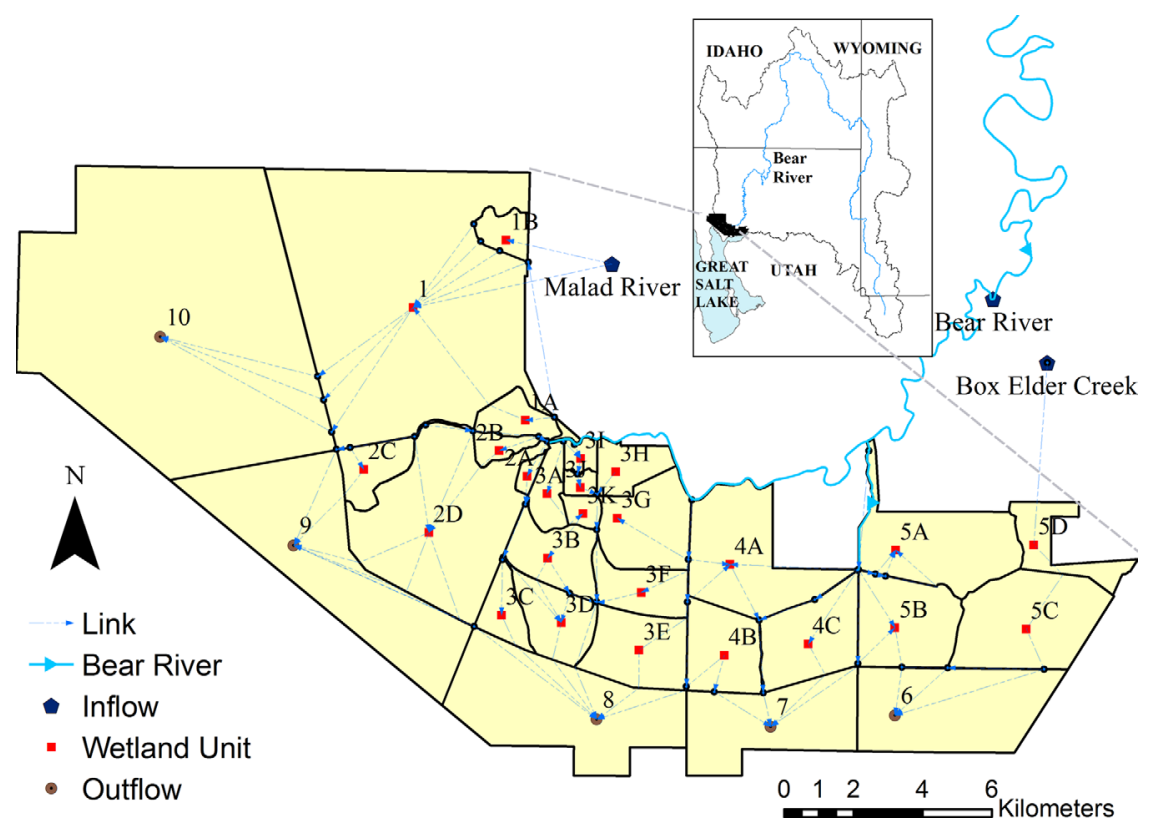

Figure 1. Bear River basin and the Bear River Migratory Bird Refuge with schematic of water inflow locations, 25 actively managed wetland units (units $1 A$ to $5 D$ ), conveyance links, and outflows (units 6-10).

have first priority under Utah water rights law to divert water to satisfy their own full, upstream, consumptive, summer irrigation uses before the Refuge can take any water [Downard et al., 2014; Kadlec and Adair, 1994].

The Refuge is also experiencing an invasion by Phragmites and Refuge managers expend considerable effort to control Phragmites with herbicides (usually glyphosate) followed by burning, mowing, or grazing to remove dead Phragmites [Kettenring et al., 2012b; Olson, 2007; Vanderlinder et al., 2014]. Since 2007, managers have prioritized control efforts in nine wetland units (typically two units per year) with Phragmites cover greater than $10 \%$.

Refuge managers are interested to learn how they can use available water and manage invasive vegetation to enhance habitat for priority bird species. Next, we describe the systems model developed to connect these hydrological and vegetation components and inform water and vegetation management at the Refuge.

\section{Model Development}

The systems model development followed six phases central to collaborative and participatory modeling [Langsdale et al., 2013; Loucks et al., 2005], including to: (i) Describe the management goal(s), (ii) Identify metrics that quantify progress toward achieving goal(s), (iii) Identify actions managers can take to reach the goal(s), (iv) Mathematically relate management actions to the metrics, (v) Identify constraints that limit actions managers can take, and (vi) Implement and solve the optimization model. Uncertainties exist at each phase which we addressed through the participatory process both by soliciting Refuge manager feedback on results from earlier phases, revisiting earlier phases as needed, and running numerous model scenario and sensitivity analyses. Manager feedback is discussed further in section 5 . Below, we present the resulting general model formulation for a diked wetland system where one or more interconnected wetland units are managed over a fixed time horizon for one or more priority species having concurrent water and vegetation habitat needs.

\subsection{Wetland Management Goals}

The overall Refuge management goal-identified through participatory meetings with managers and review of Refuge management plans [Olson, 2007; Olson et al., 2004]—is to enhance wetland habitat for priority migratory bird species. Priority species comprise a subset of some 250 bird species that occur at the 
Refuge. Species were prioritized because either their (i) populations are present at the Refuge in globally significant numbers, or (ii) habitat needs encompass the needs of other species. Enhancing habitat for priority bird species also promotes a broader set of Refuge management goals including to promote birding, fishing, hunting, wildlife viewing, conservation, and other recreation opportunities within the Refuge. Enhancing habitat for priority species differs from other ecological management efforts that instead try to restore the natural water regime or ecological state [Higgins et al., 2011; Steinschneider et al., 2013]. In diked wetlands such as at the Refuge, hydrology, soils, and vegetation are so altered and disturbed compared to the pre-European settlement state that complete or even partial return to conditions prior to the $1850 \mathrm{~s}$ is not feasible or desirable [Downard and Endter-Wada, 2013]. Instead, managers focus on the more immediate and reachable goal to improve habitat for key species.

\subsection{Performance Metric}

To quantify progress toward the goal to enhance habitat for three priority bird species [black-necked stilt (Himantopus mexicanus), American avocet (Recurvirostra americana), and tundra swan (Cygnus columbianus)], we identified the key feeding, resting, and breeding activities priority migratory bird species undertake at the Refuge, activity timings, and habitat requirements for those activities. Habitat requirements include pools of water of sufficient depth to feed and rest, as well as wetland vegetation cover in which to feed, rest, and breed. The concurrent water and vegetation habitat requirements are species- and timespecific. We then developed a weighted unit area for wetlands (WU) metric that describes the suitable area for priority bird species to undertake specified activities. The WU sums weighted products of speciesspecific suitability terms for invasive vegetation cover and water depth habitat attributes (HV and DVS in equation (1)).

$$
W U=\sum_{t, w}\left(\frac{\sum_{s} s W_{t, s} \cdot H V_{t, w, s} \cdot D V S_{t, w, s}}{\sum_{s} s w_{t, s}}\right)
$$

Here $s w_{t, s}$ is the weight in time $t$ for species $s$ (unitless), $H V_{t, w, s}$ is the vegetation cover suitability index value in time $t$ in wetland unit $w$ for species $s$ (unitless), while $D V S_{t, w, s}$ quantifies the area in wetland unit $w$ at time $t$ with suitable water depth conditions for species $s\left(\mathrm{~m}^{2}\right)$. The DVS suitable area considers spatial variations of water depths within a wetland unit by partitioning the wetland unit into zones so all points in zone $z$ have the same water depth, then summing products of species-specific water depth suitability index values $\left[H W_{w, z, s}\right.$ (unitless)] for the zone and zone area. Expressing DVS as an area allows us to quantify WU in real units (i.e., $\mathrm{m}^{2}$ ) that are easy to communicate to external audiences, observe in the field, calculate through time and spatially within and across diked wetland units.

Here and subsequently, we specify time $t$ in monthly steps for one calendar year because Refuge staff plan, schedule, and monitor management actions at monthly intervals, typically for a one year planning cycle. Because of the monthly time spacing and short planning horizon, the $W U$ metric ignores temporal discounting and assumes perfect foresight of water inflows and other inputs over the planning cycle [Draper, 2001]. At the same time, the short planning cycle makes perfect foresight and other uncertainty issues ripe for exploration through scenario and sensitivity analysis.

The invasive vegetation cover and water depth habitat suitability index values $H V$ and $H W$ take values from 0 (poor) to 1 (excellent) habitat quality to describe the capacity of each individual habitat attribute to support priority bird species. Habitat suitability curves functionally relate the index values to water depth and vegetation cover habitat attributes (see section 3.4) and this use follows two decades of work to define habitat quality for fish, alligators, birds, algae, and other wildlife species [Tarboton et al., 2004]. The multiplication of the HV suitability index and DVS suitable area terms in equation (1) means priority bird species require both suitable water depth and invasive vegetation cover conditions-water and vegetation are separate, concurrent, but nonsubstitutable habitat requirements.

Weighting the habitat suitability terms by species adapts to diked wetlands a widely used weighting approach for evaluating in-stream flow needs [Cardwell et al., 1996; Hardy, 2005; Payne, 2003]. Here the species weight sw allows managers to consider varying and possibly conflicting habitat needs of different species at different times. Although critics fault the weighting approach for focusing on limited, indicator species [King et al., 2008], here the indicator species focus explicitly follows Refuge goals to manage for 


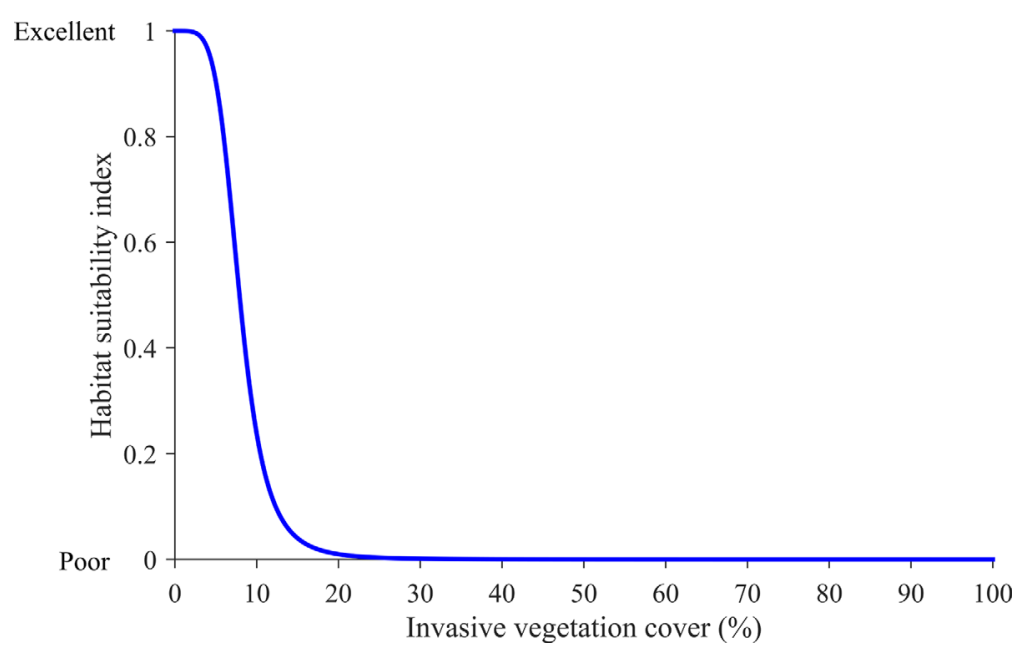

Figure 2. Example habitat suitability index for invasive vegetation cover (Phragmites).

select migratory bird species. Further, vegetation habitat suitability index values can vary through time as invasive vegetation cover changes. The $W U$ metric therefore explicitly considers water availability and invasive vegetation as key wetland stressors.

\subsection{Management Actions and Decision Variables}

To improve wetland habitat for priority bird species, managers adjust water levels in wetland units and control invasive vegetation. In the model, a first group of decision variables influence water levels in wetland units: (i) the flow rate $\left[Q_{t, i, j}\right.$ (ha-m/month)] in a canal segment during time $t$ (month) from a start location $i$ (an index) to a destination location $j$ (an alias of the index $i$ ), and (ii) the storage volume $\left[S_{t, w}\right.$ (ha-m/month)] in each time $t$ at the subset of nodes $w$ that are wetland units $(w \varepsilon i$; storage is constrained to be zero at the remaining nodes that are simple junctions). Wetland unit staff gages and observed level-storage and arealevel relationships $\left(w d_{w}\right.$ and $a_{w}$ ) further allow us to relate storage volume decision variables to additional state variables representing (iii) water level $\left[W D_{t, w}(\mathrm{~m})\right]$ and (iv) flooded area $\left[A_{t, w}\left(\mathrm{~m}^{2}\right)\right]$ in each time $t$ and wetland unit $w\left[W D_{t, w}=w d_{w}\left(S_{t, w}\right) ; A_{t, w}=a_{w}\left(W D_{t, w}\right)\right]$

A second group of model decision variables represent invasive wetland vegetation management actions and include: (i) vegetation management by burning, herbicide application, grazing, and mowing in each time step $t$ and wetland unit $w\left(R V_{t, w}\right)$, and (ii) the invasive vegetation cover $\left(I V_{t, w}\right)$ present in each wetland unit $w$ at the end of time step $t$ (both $R V$ and $I V$ are quantified as a percentage of the total wetland unit area). The complement of invasive vegetation cover (100 - IV indicates cover by native vegetation or open water. Explicitly representing invasive vegetation cover allows the model to track cover over time, vegetation response to natural factors and management efforts, and corresponding changes in habitat suitability for priority bird species.

\subsection{Relate Management Actions and Performance Metrics}

We use habitat suitability curves and the weighted usable area method presented in section 3.2 to relate the WU metric to decision variables representing water and invasive vegetation management actions. Habitat suitability curves are based on literature review, historical data, controlled experiments, and expert opinion [Hardy, 2005]. Their use allows us to (i) separately and independently assess how invasive vegetation cover and spatially varying water depth habitat attributes in wetland units meet the habitat needs of priority bird species, and (ii) tractably relate management actions to the $W U$ metric in a nonlinear systems optimization model.

Figure 2 shows how invasive vegetation (Phragmites) cover at the Refuge influences habitat suitability for the three priority bird species. Habitat suitability ranges from 1 (excellent) habitat quality when little Phragmites is present to 0 (poor) quality when Phragmites covers more than $10 \%$ of the total area of a wetland unit. At the Refuge, a small amount of Phragmites cover $(<5 \%)$ is beneficial because the plant provides some nesting strata, hiding, and thermal cover. Phragmites cover greater than $10 \%$ is undesirable because 


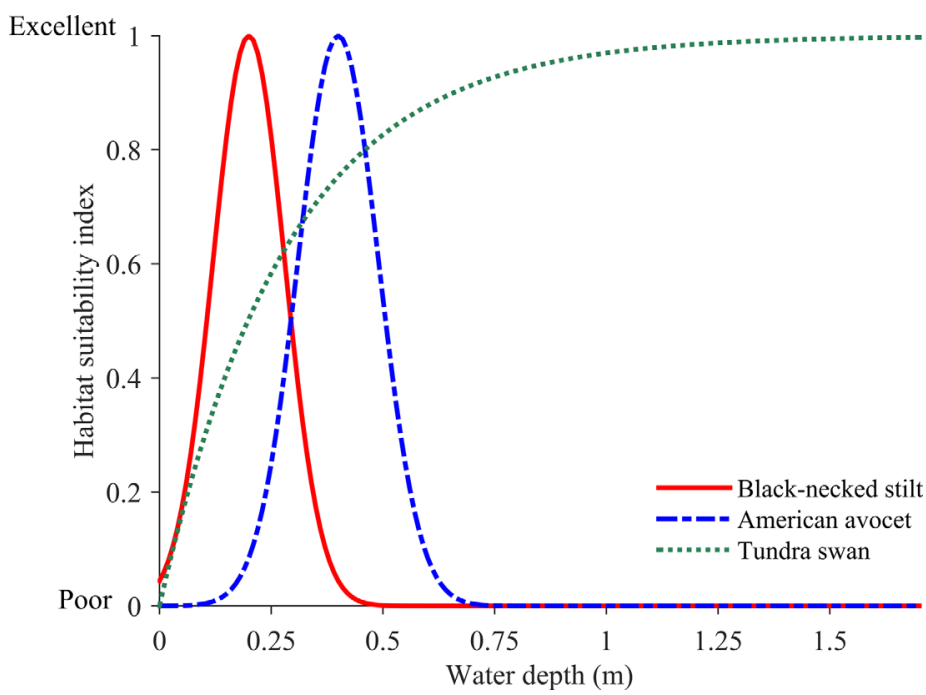

Figure 3. Habitat suitability of water depth in wetland units for three priority bird species at the Refuge. black-necked stilt cannot enter dense stands to feed or breed; also, Phragmites displaces native wetland vegetation with higher wildlife values [Olson, 2007]. Refuge managers describe 10\% Phragmites cover as a goal for invasive vegetation control efforts.

Mathematically, the habitat suitability index value for the invasive vegetation cover attribute $\left(H V_{t, w, s}\right.$ defined previously) is a function $\left(f v_{s}\right)$ of the invasive vegetation cover (equation (2)):

$$
H V_{t, w, s}=f v_{s}\left(I V_{t, w}\right), \forall t, w, s
$$

A similar function $f w_{s}$ and relationship $\left[H W_{w, z, s}=f w_{s}\left(d_{w, z}\right)\right]$ specifies the suitability of water depth $d_{w, z}$

(m) in zone $z$ of wetland unit $w$ for species $s$. We follow four steps to calculate the area with suitable water depth habitat characteristics for species $s\left(D V S_{t, w, s}\right.$ defined previously) that considers spatial distributions of water depths in wetland units. First, we partition the wetland unit into zones with the same water depth and order zones by increasing water depth $\left(d_{w, 1}<d_{w, 2}<d_{w, 3}<\ldots<d_{w, z}\right)$. Second, we calculate the suitable area for a particular wetland unit water level $W D_{t, w}$ by summing products of the zone water depth suitability index (fw) and zone area (equation (3)).

$$
D V S_{t, w, s}=d v s_{w, s}\left(W D_{t, w}\right)=\sum_{z \in\left(d_{w, z} \leq W D_{t, w}\right)} f w_{s}\left(d_{w, z}\right) \cdot\left[a_{w}\left(W D_{t, w}-d_{w, z}\right)-a_{w}\left(W D_{t, w}-d_{w, z+1}\right)\right], \forall t, w, s
$$

The summation includes each zone with water depth at or below the specified water level. Each zone area (expression in square brackets) is calculated as the difference between the wetted area of the current zone and next deeper zone; the term $(W D-d)$ converts zone water depth to a level that is used to calculate wetted area. Third, we repeat steps 1 and 2 for various water levels and each species. And fourth, we fit wetland unit- and species- specific suitable area functions $\left(d v s_{w, s}\right)$ to the results obtained in step 3 (see supporting information section S1). These four steps are taken prior to modeling; thus, the suitable area considers spatially varying water depths within wetland units without expanding the optimization model size or spatial discretization.

In equations (2) and (3), $f v_{s}$ and $d v s_{w, s}$ are continuous and smooth nonlinear functions to avoid numerical difficulties in the model solution (e.g., Figure 3 and supporting information Figure S1). Should habitat suitability have threshold effects, the function curvature can be adjusted or a smooth and more sharply transitioning function substituted (e.g., see constraint on gate changes in the next section and supporting information).

\subsection{Constraints}

Water and vegetation management decision variables are subject to hydrological, vegetation cover, and management constraints (equations (4)-(11)). One set of hydrological constraints uses a simple low-order finite-difference approximation to require water mass balance at each time $t$ and node $i$ (equation (4)), while equations (5) and (6) place minimum and maximum limits on channel conveyance and wetland unit storage.

$$
\begin{gathered}
i n_{t, i}+\sum_{j} l q_{j, i} \cdot Q_{t, j, i}-\sum_{j} Q_{t, i, j}-l e_{t} \cdot a_{i}\left(w d_{i}\left(S_{t, i}\right)\right)=S_{t, i}-S_{t-1, i}, \quad \forall t, i \\
q m_{i j} \leq Q_{t, i, j} \leq q x_{i j}, \forall t, i, j
\end{gathered}
$$




$$
s m_{i} \leq S_{t, i} \leq s x_{i}, \forall t, i
$$

Here $i_{t, i}$ (ha-m/month) is the inflow during time period $t$ at node $i ; q_{j, i}$ (unitless) is a loss coefficient in the channel from node $j$ to node $i ; e_{t}(\mathrm{~m})$ is the evaporation during time period $t ; S_{t-1, i}($ ha-m) is the storage in the previous time-step, $q m_{i, j}$ and $q x_{i, j}$ (each ha-m/month) are, respectively, the minimum and maximum flow capacities between nodes $i$ and $j$ during a time period; and $s m_{i}$ and $s x_{i}$ (each ha-m) are, respectively, the minimum and maximum water storage capacity at node $i$. Note, storage at time zero $\left(S_{0, i}\right)$ is a userprovided initial storage at node $i$. Also, setting $s m$ and $s x$ to zero defines a simple hydraulic junction with no storage and renders only the first three terms of equation (4) active. The remaining subset of nodes $w$ represents wetland units with storage $(s x>0)$. Wetland performance is measured at these nodes in equation (1).

Vegetation cover constraints dynamically track changes in invasive vegetation cover in each wetland unit $w$ through time by requiring that invasive vegetation cover in each wetland unit at the end of time step $t\left(I V_{t, w}\right)$ equal cover at the end of the prior time step $\left(I V_{t-1, w}\right)$, minus invasive vegetation controlled by managers $\left(R V_{t, w}\right)$, and plus natural growth $\left(v r_{t, w}\right)$ (all terms expressed as a percent of the wetland unit area) (equation (7)).

$$
I V_{t, w}=I V_{t-1, w}-R V_{t, w}+v r_{t, w}, \quad \forall t, w
$$

The natural invasive vegetation growth rate $(v r)$ presently reflects the $10 \%$ annual areal expansion noted by experts and reported in prior Phragmites studies under various water level, flow duration, and nutrient conditions [Kettenring et al., 2016]. In reality, hydrology [Chambers et al., 2003; Weisner and Strand, 1996], mechanism of reproduction and spread [Kettenring and Mock, 2012], plant life stage, and other environmental factors [e.g., Kettenring et al., 2011, 2015a; Rickey and Anderson, 2004] influence Phragmites growth and cover and are areas of ongoing research. We use a constant growth rate as a first attempt to represent the influence of vegetation growth. As in equation (4), invasive vegetation cover at time zero $\left(I V_{0, w}\right)$ specifies a userprovided initial invasive vegetation cover in wetland unit $w$ (percent of wetland unit area).

Vegetation management is constrained by an operating budget, $b(\$)$, for the analysis period (equation (8)). We also set upper limits on invasive vegetation management (equation (9)) which is either current invasive vegetation cover or a user specified limit, vegm $_{t}$ (percent of wetland unit area):

$$
\begin{gathered}
\sum_{t, w} R V_{t, w} \cdot t a_{w} \cdot u c_{t} \leq b \\
R V_{t, w} \leq I V_{t, w} ; R V_{t, w} \leq \operatorname{vegm}_{t}, \quad \forall t, w
\end{gathered}
$$

where $t a_{w}\left(\mathrm{~m}^{2}\right)$ is the total area of wetland unit $w, u c_{t}\left(\$ / \mathrm{m}^{2}\right)$ is the unit cost to manage invasive vegetation during time $t$, and $R V_{t, w}$ and $I V_{t, w}$ are the control percentage and invasive vegetation cover (defined previously). Unit costs in equation (8) reflect costs for labor, equipment operation, and materials that are proportional to the area controlled and vary temporally because managers mow, burn, and apply herbicides at different times in the year.

An additional constraint limits the number of manual operations to open or close wetland unit gates in a time step $\left(G_{t}\right)$ to no more than the total operations allowed by available Refuge staff time and personnel $\left(a g_{t}\right)$ (equation (10)).

$$
G_{t} \leq a g_{t}, \forall t
$$

Here we use a smooth, sharply transitioning sigmoidal function to calculate counts of manual operations to open and close wetland unit gates $\left(G_{t}\right)$ from changes from one time step to the next of water flow decision variables into and out of wetland units. A more detailed discussion of the methodology to determine this sigmoidal function and the numerous approaches tested [e.g., Grossmann et al., 2002] can be found in the supporting information.

A final set of constraints requires the decision variables $S, Q, W D, I V, R V$, and $G$ to be nonnegative. Together, maximizing the objective function (equation (1)) subject to constraints (equations (2)-(10)) comprises a nonlinear optimization model.

\subsection{Additional Management Constraints}

Additional management constraints allow managers to simulate wetland performance under past observed hydrological conditions, allocate predetermined volumes of water to particular wetland units, or specify 
Table 1. Water Depth Habitat Needs and Manager Weights for Priority Birds Species Weight (0 (not desired) to 1 (desired))

\begin{tabular}{|c|c|c|c|c|c|c|c|c|c|c|c|c|c|}
\hline \multirow[b]{2}{*}{ Species } & \multirow{2}{*}{$\begin{array}{c}\text { Water } \\
\text { Depth Need }\end{array}$} & \multicolumn{12}{|c|}{ Weight (0 (not desired) to 1 (desired)) } \\
\hline & & Jan & Feb & Mar & Apr & May & Jun & Jul & Aug & Sep & Oct & Nov & Dec \\
\hline Black- necked stilt & Shallow & 0.1 & 0.1 & 0.1 & 0.8 & 0.8 & 0.8 & 0.6 & 0.6 & 0.25 & 0.1 & 0.1 & 0.1 \\
\hline American avocet & Medium & 0.1 & 0.1 & 0.6 & 1 & 1 & 1 & 1 & 1 & 1 & 0.6 & 0.1 & 0.1 \\
\hline Tundra swan & Deep & 1 & 1 & 1 & 0.3 & 0.1 & 0.1 & 0.1 & 0.1 & 0.1 & 0.1 & 1 & 1 \\
\hline
\end{tabular}

hydrologic conditions to reach goals that are not otherwise included in the model. Users can specify the constraints for a subset of prior observed or desired storage volumes ( $d s_{t^{\prime}, w^{\prime}}$ ) at specified times $t^{\prime}$ in select wetland units $w^{\prime}$ (equation (11)):

$$
S_{t^{\prime}, w^{\prime}}=d s_{t^{\prime}, w^{\prime}}, \quad \forall t^{\prime} \in t, w^{\prime} \in w
$$

Examples uses include requiring specific water depths in wetland units to provide recreation or hunting services (not explicitly represented in the objective function) or drain and dry wetland units for maintenance or control for avian diseases like botulism.

\subsection{Model Scenarios and Input Data}

The base case model scenario represents the 2008 calendar year. The Refuge water distribution network comprises 3 inflow water sources (Bear River, Malad River and Box Elder Creek), 25 wetland units, 70 junctions, 5 outlets, and 153 canal segments (Figure 1). Inflow data for the Bear River were obtained from the United States Geological Survey (station \#10126000, Bear River near Corinne, UT). For the Malad River and Box Elder Creek, some inflow data were obtained from nearby private property owners such as the Bear River Club (a duck hunting organization). In other cases, we correlated missing gauge records with Bear River flows at the Corinne station.

From the 20 priority bird species listed in the Refuge Habitat Management Plan [Olson et al., 2004], we and the Refuge managers identified three priority bird species (black-necked stilt, American avocet, and tundra swan), their habitat requirements, and corresponding habitat suitability curves to include in the modeling. We selected these species because they need different shallow, medium, and deep water conditions (Figure 3) at different times of the year (Table 1) and because these needs encompass needs of other priority bird species. For example, black-necked stilt are present at the Refuge between April and September and prefer shallow water depths between 0.15 and $0.25 \mathrm{~m}$ to feed. During the same time, up to $55 \%$ of the continental avocet population uses the Refuge to feed, nest, brood, rear hatchlings, and stop during migration before departing for other wintering grounds. Avocets feed deeper below the water surface $(0.35 \mathrm{~m}-0.45 \mathrm{~m})$. Refuge managers assign a high priority species weight $s w$ to avocets because there is a large avocet population that has diverse feeding, resting, and breeding activities at the Refuge. In contrast, tundra swan use the Refuge as a staging area and migratory stopover during winter months, can tolerate shallow or medium depth waters, but prefer to feed and rest in water greater than $0.55 \mathrm{~m}$ [Olson et al., 2004]. Each priority bird species has similar habitat needs for native vegetation as discussed in section 3.4 (Figure 2).

We used Refuge staff observations of wetland unit water levels and our estimates of Phragmites cover at the beginning of 2008 to define the initial water and vegetation conditions in each wetland unit. Initial Phragmites cover was estimated between 0 and $6 \%$ by reducing classifications of readily available Landsat $30 \times 30 \mathrm{~m}$ satellite imagery in 2008 by factors of $0.03-0.36$. These factors represent the amounts by which similar Landsat classifications for 2010 overestimated Phragmites cover in select wetland units compared to 2010 classifications from high-resolution (1x1 m) airborne remote sensed imagery [Vanderlinder et al., 2014].

We used monthly pan evaporation rates (without crop coefficients) from the Western Regional Climate Center (http://www.wrcc.dri.edu/) to estimate the integrated effects of radiation, temperature, wind, and humidity on evaporation from wetland surfaces absent site-specific observations of wetland evapotranspiration $(\mathrm{ET})$ rates. Although wetland evapotranspiration rates can be effected by local weather, vegetation composition and structure, water depth, and surrounding land features, pan evaporation rates are typically larger than open-water evaporation rates [Allen, 1998], which, in turn, are larger than ET rates from vegetated wetlands [Stannard et al., 2013]. Thus, pan evaporation rates likely overestimate evaporative losses and underestimate wetland performance, an effect we later test in sensitivity analyses. When available, rates 
from alternative, more site-specific methods to estimate ET (e.g., hydro-meteorological equations, eddy covariance, remote sensing) can be substituted.

Remaining model input data were obtained from: (i) studies of Refuge water requirements [Christiansen and Low, 1970; Kadlec and Adair, 1994], and (ii) management and field data provided by Refuge staff, including the Refuge operating budget, August to November operational window to manage Phragmites [Kettenring et al., 2015b], observed water levels in wetland units, and wetland unit water level-storage-flood area profiles derived from LiDAR.

We used the input data to define a base case scenario that simulated $W U$ for the water levels that Refuge managers set in $2008\left(S_{t^{\prime}, w^{\prime}}=d s_{t^{\prime}, w^{\prime}}\right.$, equation (11)), existing Phragmites management budget of $\$ 180,000 /$ year, Phragmites management costs of $\$ 0.20 / \mathrm{m}^{2}$, Phragmites growth of $10 \%$ per year prorated over the April to November growing season, and only allowing water levels to change in four wetland units per month (current Refuge staffing limits; equation (10)). Scenario 1 removed the equation (11) constraints $\left(S_{t^{\prime}, w^{\prime}}=d s_{t^{\prime}, w^{\prime}}\right)$ and recommended water levels and Phragmites management that increase WU. Scenario 2 further relaxed the gate management constraint (equation (10)) to allow staff to change water levels as often as needed. Although numerous gate changes are not currently feasible with manual operation, such changes are possible were the Refuge to install a remote-operated and computer-controlled gate system (the capital costs of which are not considered here). Scenario 3 also allowed numerous gate changes but set the initial Phragmites cover and growth rate parameters ( $I V_{0}$ and $v r$ in equation (7)) to zero to isolate effects of hydrological habitat components on wetland performance. Scenarios 4 and 5 increased the initial Phragmites cover $I V_{0}$ in equation (7) by factors of 2 and 3 over the initial cover estimates for 2008. Additional sensitivity runs further modified the evaporation and inflow parameters in equation (4) to identify effects of (a) substituting reference ET rates for alfalfa measured in Perry, Utah that were lower than pan evaporation rates by $0.04-$ $0.15 \mathrm{~m} / \mathrm{month}$ from April to October (Utah Climate Center, https://climate.usurf.usu.edu/mapGUI/mapGUI. php) and (b) water availability observed in years representing dry (1992), intermediate (1996 and 20042011), and wet (1997) conditions.

The model for the Refuge was implemented using the General Algebraic Modeling System (GAMS), has approximately 6,300 decision variables and 9,700 constraints, and was solved using the nonlinear CONOPT solver [Rosenthal, 2014]. Although nonlinear solvers such as CONOPT may prematurely terminate at local optima, our testing varied starting water levels between 0 and $3.5 \mathrm{~m}$ in each wetland unit (the lower and upper bounds), and showed CONOPT solved each scenario in a few minutes and gave similar temporal and spatial patterns of recommended water levels with only minor variations in wetland performance. In comparison, two global solvers (BARON and COUENE) either returned an infeasible solution or ran for $30+$ days without returning a solution. Testing showed CONOPT as more suitable for scenario and sensitivity analysis and that local optima can still identify substantial improvements over current management. We used Matlab to process model inputs and outputs and graphically display results. All input data, model code, and scripts are available at https://github.com/alminagorta/Systems-model-in-Wetlands-to-Allocate-water-andManage-Plant-Spread.

\subsection{Model Outputs}

Key model outputs comprise reports, time series, and maps that show model recommended water levels and vegetation control actions in wetland units and how actions affect the overall WU metric and $W U$ in individual wetland units. Additional outputs include a composite habitat suitability $\left[H C_{t, w}\right.$ (unitless; ranging from 0 to 1)] which is the expression in parenthesis in equation (1) divided by the wetland unit surface area and represents concurrent water depth, vegetation cover, and species prioritization suitability factors. Shadow value (Lagrange multiplier) results associated with water mass balance and financial budget constraints (equations (4) and (8)) further show how water availability and vegetation management affect overall wetland performance. Comparing results across scenarios identifies the individual and combined effects on WU of water and vegetation system components.

\section{Results}

Comparing results from the prior management (base case) and the first model recommended scenario shows there are opportunities at the Refuge to increase nearly twofold the available surface area that 


\begin{tabular}{|c|c|c|c|c|c|}
\hline \multirow{2}{*}{\multicolumn{2}{|c|}{ Scenario }} & \multicolumn{4}{|c|}{ Table 2. Model Scenarios and Results } \\
\hline & & $\begin{array}{l}\text { Gate Changes } \\
\text { Per Month }\end{array}$ & $\begin{array}{l}\text { Initial Invasive } \\
\text { Vegetation Cover } \\
\text { (Fraction of 2008) }\end{array}$ & $\begin{array}{c}\text { Weighted } \\
\text { Usable Area for } \\
\text { Wetlands ( } \mathrm{km}^{2} / \mathrm{yr} \text { ) }\end{array}$ & $\begin{array}{c}\text { Shadow Value } \\
\text { of Budget } \\
\text { Constraint }\left(\mathrm{m}^{2} / \$\right)\end{array}$ \\
\hline & Previous Management (Base Case) & 4 & 1 & 377 & 2.56 \\
\hline 1 & Model Recommendation & 4 & 1 & 715 & 6.75 \\
\hline 2 & Automatic Gates & unlimited & 1 & 827 & 6.73 \\
\hline 3 & No Invasive Vegetation or Growth & unlimited & 0 & 833 & 0 \\
\hline 4 & Increased Invasive Vegetation & unlimited & 2 & 742 & 194.5 \\
\hline 5 & Increased Invasive Vegetation & unlimited & 3 & 673 & 77.5 \\
\hline
\end{tabular}

provides suitable hydrological and vegetation conditions for the three priority bird species (Table 2). To achieve this increase, the model recommends to more dynamically vary water levels in most wetland units (Figure 4, red lines). More dynamic management typically raises water levels during January, February, and March, gradually lowers levels through the spring and summer, and again raises levels in the early winter (units 1, 1A, 1B, 2A, 2D, 3A, 3C, 3I, 3K, 4A, 5A, 5B, 5C, 5D). These actions also maintain water in units 3B, 3D, $3 \mathrm{E}, 3 \mathrm{~F}, 3 \mathrm{~J}$, and $4 \mathrm{C}$ through critical summer months and contrast with either the near-constant water levels managers maintained throughout 2008 or summer months when managers dried several units (Figure 4, blue bars).

With more dynamic management, composite habitat suitability $(H C)$ for priority bird species is highest during winter (Figure 5). April through October are particularly critical months when most wetland units show poor conditions except for units $2 \mathrm{~B}$ and $4 \mathrm{~B}$ that maintain $\mathrm{HC}$ values greater than 0.4 all year. The model concentrates Phragmites management in seven wetland units in August at the beginning of the window for management operations to achieve or sustain excellent habitat suitability of vegetation cover for the duration of the year (supporting information Figures S3 and S4). Thus, temporal and spatial variations in $H C$ are largely due to the water depth habitat component.

Shadow values (Lagrange multipliers) associated with the water mass balance constraint (equation (4)) show that one additional ha-m of Bear River water will most increase wetland performance in the months of July, August, September and October (Table 3). In contrast, the shadow value associated with the financial budget constraint (equation (8)) is low (Table 2).

Further scenario analysis shows that installing a system of automatic gates (i.e., staff can adjust water levels in wetland units as often as they need) improves wetland performance a further $15 \%$ in comparison to the

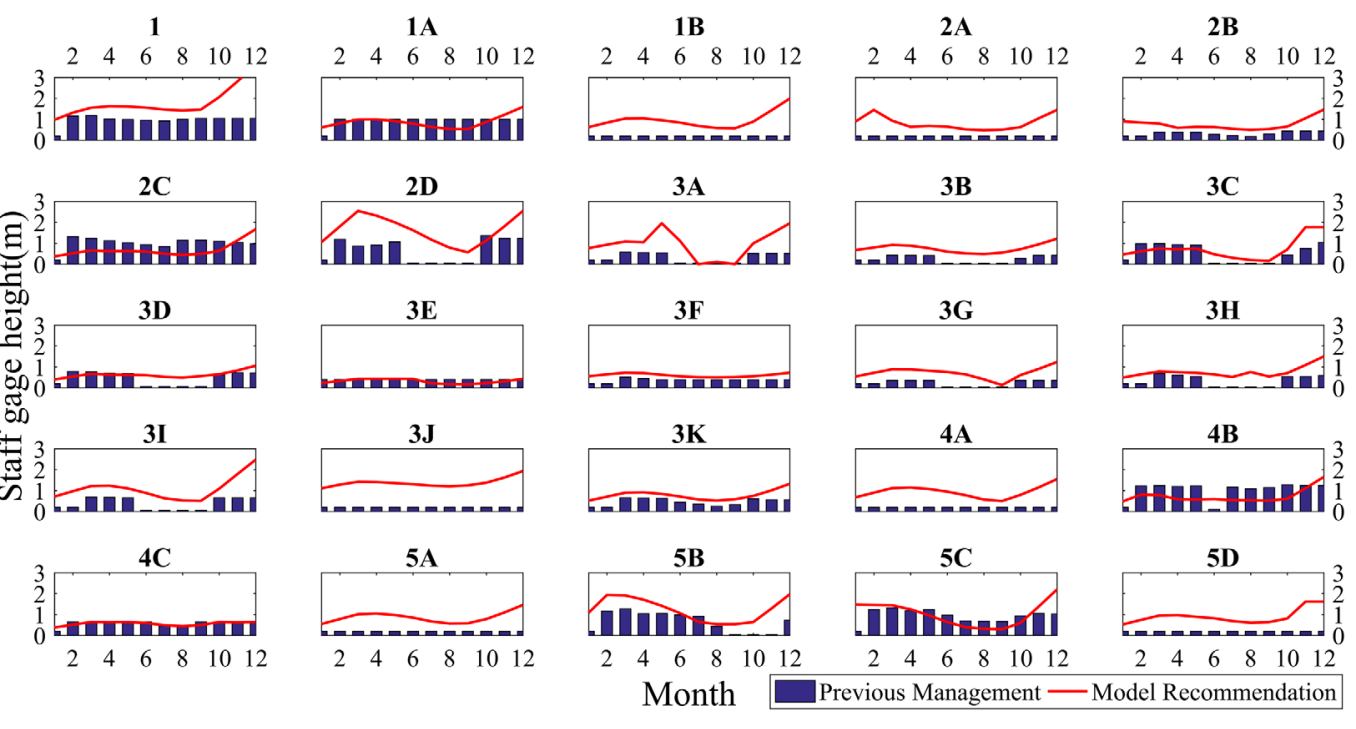

Figure 4. Comparison of model recommended (optimized, red line) and previous management (simulated, blue bars) staff gage height by month and wetland unit during 2008. 

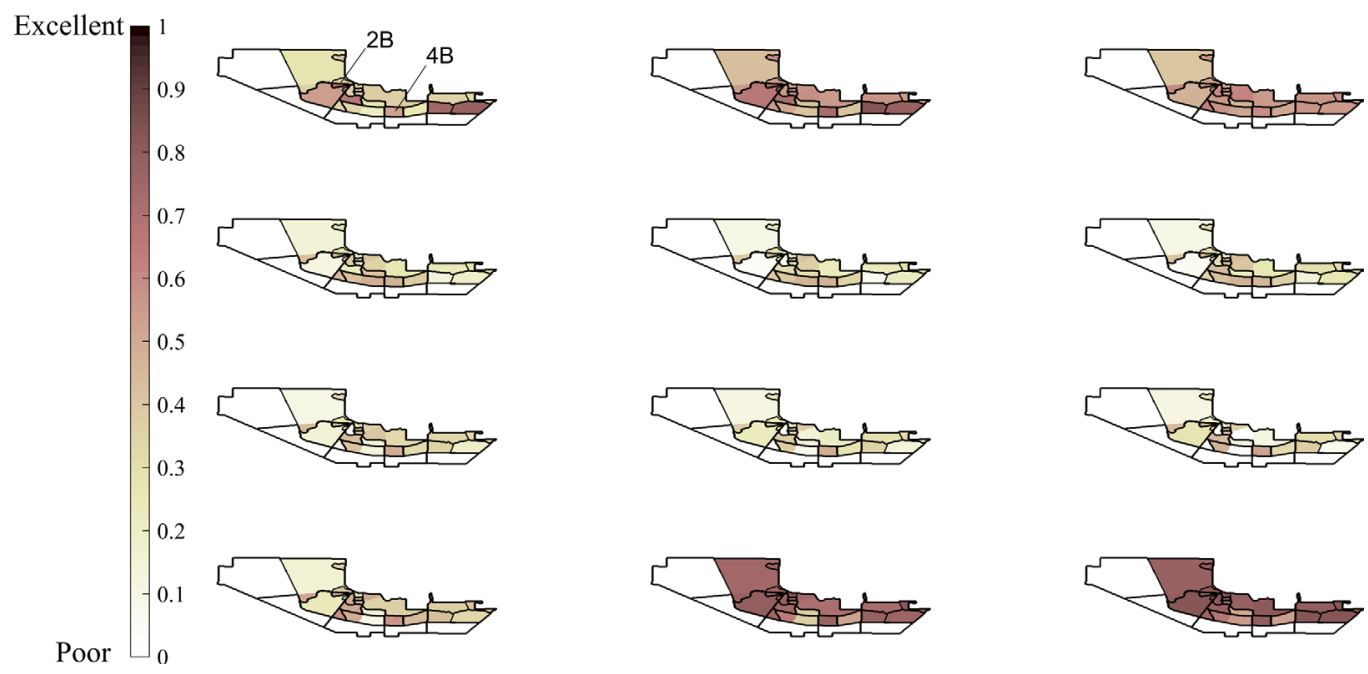

Figure 5. Spatial and temporal distribution of composite habitat suitability index (HC) for optimized case (scenario 1) in 2008. Dark shading denotes areas with water depths and vegetation cover more suitable for the three priority bird species.

first scenario (Table 2). Model recommendations absent Phragmites (Scenario 3) offer a further small increase in wetland performance compared to the automatic gates scenario. Here habitat suitability for vegetation is always excellent, water depth is the sole factor that influences wetland performance, and the scenario emulates prior systems modeling studies that use only a flow-based ecological objective. In contrast, increasing initial Phragmites cover by factors of two or three over the cover values estimated for 2008 (Scenarios 4 and 5) decreases wetland performance compared to Scenario 3, increases the shadow value associated with the financial budget for Phragmites management, and alters the magnitudes and timings of water allocations in 15 of the 25 wetland units (supporting information Figure S5).

Sensitivity analyses that used reference evaporation rates for alfalfa in the base case, automated gates, and scenarios that increased initial invasive vegetation cover showed that wetland performance increased by $0-20 \mathrm{~km}^{2} / \mathrm{yr}$ ( $0 \%$ to $2.6 \%$ ) over the runs that used pan evaporation rates. Further sensitivity analyses simultaneously varied the initial Phragmites cover and water availability observed in years 1992, 1996, 1997, and 2004-2011 and show three linkages among hydrological and vegetation system components (Figure 6). First, there is a nonlinear relationship between wetland performance and water availability regardless of the initial Phragmites cover. Second, runs with initial invasive vegetation cover at levels estimated for 2008 perform nearly identical to runs with zero Phragmites cover. And third, as initial Phragmites cover and water availability increase, the difference in wetland performance with respect to the no Phragmites condition grows both absolutely and relatively.

\begin{tabular}{lc}
$\begin{array}{l}\text { Table 3. Increase in Weighted Usable Area for Wetlands per } \\
\text { Additional Unit of Water in Scenario } 1 \text { of Optimized Management } \\
\text { Shadow Value of } \\
\text { Water Mass Balance } \\
\left.\text { Constraint ( } \mathrm{m}^{2} / \mathrm{ha}-\mathrm{m}\right)\end{array}$ \\
Month & 0 \\
Jan & 0 \\
Feb & 0 \\
Mar & 0 \\
Apr & 0 \\
May & 0 \\
Jun & 45,840 \\
Jul & 4,356 \\
Aug & 47,220 \\
Sep & 523 \\
Oct & 0 \\
Nov & 0 \\
Dec & 0 \\
\hline
\end{tabular}

\section{Discussion}

Model results suggest ways to better manage the linked hydrologic and vegetation components of the diked wetland system to improve habitat for priority bird species. The scenarios of model-recommended and past management show that there are opportunities to increase by nearly two-fold the suitable wetland habitat area. This increase can be achieved by more dynamically managing water levels in the wetland units and partially controlling Phragmites in a larger number of wetland units rather than in only two units per year where Refuge staff typically undertake full control. The scenario that relaxes restrictions on gate operations further 


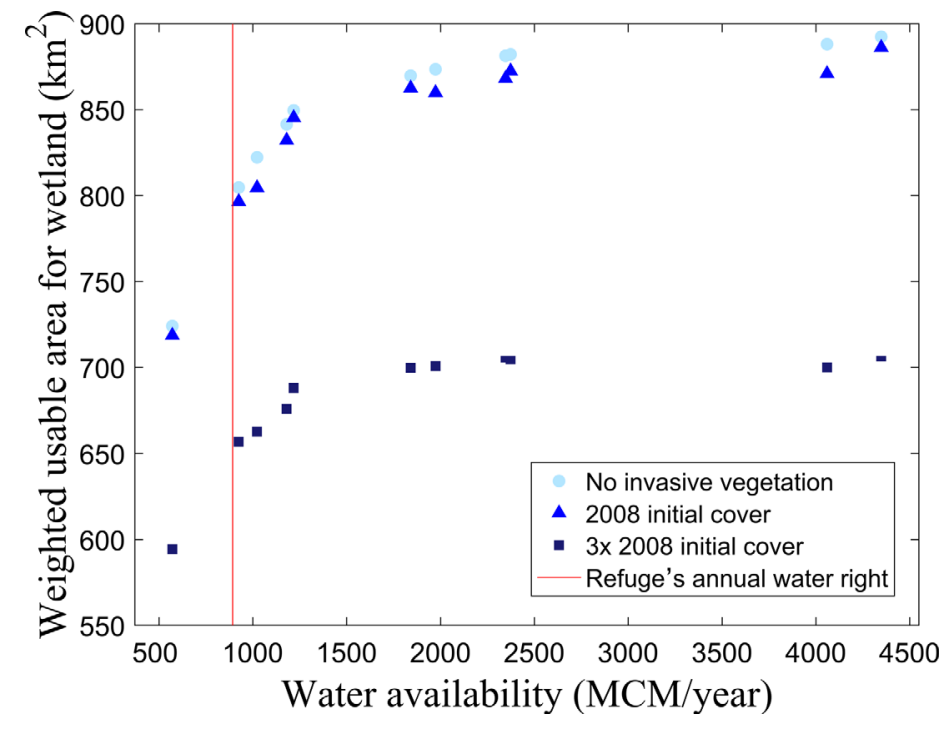

Figure 6. Weighted usable area for wetlands (y-axis) as a function of water availability (x-axis) and initial invasive vegetation cover (traces). The red vertical line shows the Refuge's annual water right. suggests operational flexibility to manage water can improve wetland performance and Refuge managers should investigate options to install an automatic system to control gates and weirs throughout the Refuge. And while prior work has also identified the need for early detection and rapid response to control invasive vegetation [NISC, 2003], here our model results suggest how to spatially configure responses among wetland units and coordinate response with other habitat factors like hydrologic conditions. In scenarios 1 and 2 with optimized management and unlimited gate changes, the low shadow values associated with the vegetation management budget constraint and small increase in

wetland performance when no Phragmites was present initially suggest that there may be little value to explicitly represent vegetation in the systems model. In other words, one could adequately define ecological objectives from only flow variables as in prior systems modeling studies [Cardwell et al., 1996; Higgins et al., 2011; Loucks, 2006; Steinschneider et al., 2013; Stralberg et al., 2009; Szemis et al., 2014]. In these scenarios, Phragmites cover had a seemingly small influence because cover was low relative to managers' target of $10 \%$ cover and habitat suitability of vegetation stayed at or close to a value of 1 (excellent). Also, there was sufficient budget to manage and maintain low Phragmites cover throughout the 1 year planning horizon.

However, subsequent scenarios and sensitivity runs suggest that much higher levels of initial Phragmites cover will noticeably decrease wetland performance (Figure 6). Thus, we interpret the scenario with no Phragmites cover or growth as an upper bound on wetland performance. Systems models that only consider the hydrologic habitat needs of priority species may overestimate performance and mischaracterize the relationship between performance and water availability when species have concurrent habitat needs for wetland plant vegetation or needs are driven by additional abiotic or biotic factors such as vegetation cover.

The scenario and sensitivity results in Figure 6 suggest three further related strategies to manage water and vegetation at the Refuge. First, maintain water availability above the existing Refuge water right of 89,300 ha-m/yr (Figure 6; red vertical line) to prevent a sharp decline in wetland performance. Second, apply additional available water in July, August, and September when shadow values associated with the water mass balance constraint are largest (Table 3). And third, the largest increases in wetland performance per unit of available water or per dollar of budget available to manage Phragmites occur when Phragmites cover is near managers' $10 \%$ cover target (Figure 6 and Table 2). Thus, Refuge managers should be concerned about upstream water abstractions that reduce available water and should also focus Phragmites control in wetland units where management can maintain or return vegetation cover to conditions that are suitable for priority birds.

While the model tracks water level and vegetation changes through time (Figure 5 and supporting information Figure S3), the summation across time in equation (1) does not explicitly consider time-dependent effects such as rapid water level changes like a wetland unit progressing from full to dry to full over three successive months. These changes would not affect the breeding activities of American avocets and blacknecked stilt that nest on small islands in the wetland units and along the crown of dikes [Olson et al., 2004]. However, rapid changes could disrupt breeding or rearing activities for other bird species or stress many wetland plant species. To limit these effects, the modeler can further adjust the species weights, limit the number of gate changes per month (ag in equation (10)), or add a new species with its own habitat requirements and species weights. 
The model also assumes Phragmites is uniformly distributed across wetland units, has linear growth over time, and no growth interactions with water level. Phragmites temporal and spatial growth and expansion is also influenced by the mechanisms of plant reproduction, salinity, and anthropogenic disturbance [Chambers et al., 1999; Kettenring et al., 2011, 2012a, 2015a, 2016], and future work should better incorporate these linked effects. Remotely sensed images, controlled field experiments, and simulation modeling at finer spatial resolutions can provide the empirical data to further specify these hydrological-plant response relationships and mathematically represent them in the systems model.

The model also determines water levels and vegetation management with perfect foresight about future water availability. The assumption of perfect foresight is common and often problematic in optimization modeling studies of reservoirs and other water storage structures [Draper, 2001]. But the effect is limited in the Refuge application for four reasons. First, the 1 year modeling horizon is short. Second, the Bear River is a snow-melt dominated basin and managers already reliably use winter snowpack levels during their annual planning each winter to forecast spring and summer water availability. Third, Refuge wetland units have relatively little storage capacity compared to the monthly flows that pass through. For example, modeled residence times in wetland units are often only one month, commensurate to the model time step. Thus, even with perfect foresight about future water availability, the model has limited ability to store water for later benefit. And fourth, when managers are uncertain about water availability, they can run the model for multiple flow availability scenarios such as shown in Figure 6.

The model sums wetland performance across wetland units and thus does not preference large contiguous areas over multiple, small fragmented areas having the same total area, water and vegetation conditions. Further, multiplying habitat suitability terms for invasive vegetation cover and water depth reflects priority bird species concurrent needs for suitable vegetation and water habitat conditions at the same time in the same wetland unit. Wetland performance can alternatively be estimated as a geometric mean that implies compensatory relationships between individual suitability indices [Waddle, 2001] for water and vegetation. Sensitivity runs that used a geometric mean showed wetland performance increased compared to the multiplicative formulation used in equation (1) (supporting information Figure S6). These runs preserved the same relative ordering of WU across scenarios and had similar spatial and temporal patterns of recommended water levels except for select differences in a few wetland units in a few months. Differences in $W U$ values were more pronounced as initial invasive vegetation cover increased and show that the method to mathematically aggregate habitat suitability attributes can influence the objective function value and this influence strengthens as a habitat factor, like invasive vegetation cover, departs from suitable conditions.

There will likely be benefit to include additional habitat attributes and suitability variables in the model besides the hydrologic and vegetation components we consider. With available input data, we could extend the model to include variables and suitability indexes for salinity or nutrient levels, substrate cover, temperature, and/or native vegetation. Including these abiotic and biotic factors and components will require field data and a more explicit description of the underlying ecology to describe current conditions, empirically relate variable values to habitat suitability, and combine suitability indexes.

Lastly, Refuge managers' participation in the work offered several benefits, including to: (i) ensure the model addresses an actual habitat management problem, (ii) populate the model with current data, (iii) help validate and interpret results, and (iv) focus recommendations on actions managers can implement. For example, after we presented a first set of model results that extensively varied water levels in wetland units from month-to-month, Refuge managers said they liked the results but could not implement them because of limited staff and time to adjust gates and weirs. Thus, we added equation (10) to restrict gate operations and reinterpreted results from that scenario to indicate the potential benefits of an automatic water control system. In continuing work, managers want to expand the number of priority species, include salinity and long-term water shortages, and use the model in their annual planning of water and vegetation management.

\section{Conclusions}

In arid regions, scarce water and invasive vegetation are common problems that affect wetland management for ecosystem functions and services. While prior systems modeling efforts have focused on water management to improve flow-based habitat objectives, here we consider water and Phragmites 
management to improve hydrologic and vegetation habitat for priority wetland bird species. We formulate a composite weighted usable area for wetlands $(W U)$ objective that represents the wetland surface area that provides suitable water depth and vegetation cover conditions for priority bird species. Maximization of $W U$ is subject to constraints on water balance, hydraulic infrastructure capacity, invasive vegetation growth and control, and a limited financial budget to control vegetation. Application at the Bear River Migratory Bird Refuge, the largest wetland complex on the Great Salt Lake, Utah, suggests that managers can nearly double the area of suitable wetland habitat by more dynamically changing water levels, managing invasive vegetation at the beginning of the window for management operations, and partially controlling Phragmites in a larger number of wetland units. Also managers can further improve wetland performance by installing an automatic gate control system to more flexibly vary water levels. There may be little benefit to include the vegetation component in the model at low invasive vegetation cover levels such as in 2008 at the Refuge. However, we observe pronounced effects on wetland performance should invasive vegetation cover approach or exceed the Refuge target of 10\% Phragmites cover. At these higher vegetation disturbance levels, systems models that look at only the hydrologic habitat needs of priority species may overestimate performance and mischaracterize the relationship between performance and water availability.

Jointly considering wetland hydrology and vegetation further emphasizes that managers should protect the Refuge's water rights. Acquiring additional water by expanding their water rights portfolio can achieve the most habitat benefit in the months of July, August, and September. Also, managers should focus Phragmites management in wetland units where they can maintain or return habitat to excellent conditions. Future work should identify dynamic vegetation responses to water levels through time and extend the wetland performance metric to consider additional abiotic and biotic factors that affect bird habitat. Together, the work links hydrologic and vegetation components of a diked wetland system and recommends coordinated water and vegetation management to improve habitat for priority species.

\section{Notation}

$A_{t, w} \quad$ Flood area in time $t$ at each wetland unit $w, \mathrm{~m}^{2}$.

$a g_{t} \quad$ Number of wetland units whose gates or weirs can be manipulated (opened or closed) in time $t$.

$b \quad$ Total budget per year to reduce invasive vegetation, $\$ /$ year.

$d_{w, z} \quad$ Water depth in wetland unit $w$ in zone $z, \mathrm{~m}$.

$d s_{t, w} \quad$ Specified (simulated) water volume in time $t$ for wetland unit $w$, ha-m.

$d v s_{w, s} \quad$ Function that relates water level in wetland unit $w$ to area in the wetland unit having suitable water depth habitat for species $s, \mathrm{~m}^{2}$.

$D V S_{t, w, s} \quad$ Area within wetland unit $w$ at time $t$ that has suitable water depth conditions for species $s, \mathrm{~m}^{2}$.

$f w_{s} \quad$ Function that relates habitat suitability and water depth for priority species $s$.

$\mathrm{fv}_{s} \quad$ Function that relates habitat suitability and invasive cover vegetation for priority species $s$.

$G_{t} \quad$ Number of manual operations required to open or close wetland unit gates in a time $t$.

$H \quad$ Habitat suitability indices.

$H C_{t, w} \quad$ Composite habitat suitability index for hydrologic and ecologic conditions in time $t$ at wetland unit $w$, unitless.

$H V_{t, w, s} \quad$ Habitat suitability index related with invasive vegetation cover in time $t$ at wetland unit $w$ for priority species $s$, unitless.

$H W_{w, z, s} \quad$ Habitat suitability index related with water depth in wetland unit $w$ in zone $z$ for priority species $s$, unitless.

in $_{t, i} \quad$ Inflow in time $t$ at node $i$, ha-m/month.

$I_{t, w} \quad$ Invasive vegetation cover in time $t$ in wetland unit $w, \%$.

le $t_{t} \quad$ Rate of evaporation loss during time period $t, \mathrm{~m}$.

$l q_{j, i} \quad$ Loss coefficient from node $j$ to node $i$, unitless.

$Q_{t, i j} \quad$ Flow rate from node $i$ to node $j$ during time period $t$, ha-m/month.

$q m_{i, j} \quad$ Minimum required flow from node $i$ to node $j$ during time period $t$, ha-m/month.

$q x_{i, j} \quad$ Maximum allowable flow from node $i$ to node $j$ during time period $t$, ha- $\mathrm{m} / \mathrm{month}$.

$R V_{t, w} \quad$ Managed invasive vegetation cover in time $t$ at wetland unit $w, \%$.

$S_{t, w} \quad$ Storage in time $t$ and wetland unit $w$, ha-m. 
$s m_{i} \quad$ Minimum storage in node $i$, ha-m.

$s x_{i} \quad$ Maximum storage in node $i$, ha-m.

$s W_{t, s} \quad$ Weight in time $t$ for priority species $s$, unitless.

$t a_{w} \quad$ Area of wetland unit $w, \mathrm{~m}^{2}$.

$u c_{t} \quad$ Unit cost of managing invasive vegetation in time $t, \$ /$ month.

vegm $_{t} \quad$ Upper limit on invasive vegetation managed in time $t, \%$.

$v r_{t, w} \quad$ Natural vegetation response in time period $t$ and wetland unit $w, \%$.

$v s_{t} \quad$ Invasive vegetation spreads at time period $t, \%$.

$W D_{t, w} \quad$ Water level at time $t$ in wetland unit $w, \mathrm{~m}$.

$W U_{t, w} \quad$ Weighted usable area wetland in time $t$ and wetland unit $w, \mathrm{~m}^{2}$.

\section{Acknowledgments}

This research was funded by the Utah Water Research Laboratory, Utah Mineral Lease funds, and partially funded by National Science Foundation grant \#1149297. We thank the Bear River Migratory Bird Refuge managers and wildlife biologists, particularly Bridget Olson, Bob Barrett, Sharon Vaughn, Katie McVey and Howard Browers for their participation, feedback, and support. Model input data, source code, and post-processing scripts are available under a BSD 3-Clause license at https://github. com/alminagorta/Systems-modelin-Wetlands-to-Allocate-water-andManage-Plant-Spread.

\section{References}

Ailstock, M. S., C. M. Norman, and J. P. Bushmann (2001), Common Reed Phragmites australis: Control and effects upon biodiversity in freshwater nontidal wetlands, Restoration Ecol., 9(1), 49-59, doi:10.1046/j.1526-100x.2001.009001049.x.

Allen, R. G. (1998), Predicting evapotranspiration demands for wetlands, paper presented at ASCE Wetlands Engineering and River Restoration Conference, Denver, Colo., 20-29 March.

Anderson, L., D. Strong, E. Millis, T. Stonely, K. Short, E. Klotz, T. Adams, and E. Edgley (2004), Utah State Water Plan, Bear River BasinPlanning for the Future, Utah Division of Water Resources, Salt Lake City, Utah.

Batzer, D. P., and R. R. Sharitz (2014), Ecology of Freshwater and Estuarine Wetlands, 2nd ed., Univ. of Calif., Oakland.

Cardwell, H., H. I. Jager, and M. J. Sale (1996), Designing instream flows to satisfy fish and human water needs, J. Water Resour. Plann. Manage., 122(5), 356-363, doi:10.1061/(ASCE)0733-9496(1996)122:5(356).

Chambers, R. M., L. A. Meyerson, and K. Saltonstall (1999), Expansion of Phragmites australis into tidal wetlands of North America, Aquat. Bot., 64(3-4), 261-273. [Available at http://www.sciencedirect.com/science/article/pii/S0304377099000558.]

Chambers, R. M., D. T. Osgood, D. J. Bart, and F. Montalto (2003), Phragmites australis invasion and expansion in tidal wetlands: Interactions among salinity, sulfide, and hydrology, Estuaries, 26(2), 398-406, doi:10.1007/BF02823716.

Christiansen, J. E., and J. B. Low (1970), Water requirements of waterfowl marshands in Northern Utah, report number 69-12, Utah Div. of Fish and Game, Salt Lake City.

Downard, R., and J. Endter-Wada (2013), Keeping wetlands wet in the western United States: Adaptations to drought in agriculturedominated human-natural systems, J. Environ. Manage., 131, 394-406. [Available at http://www.sciencedirect.com/science/article/pii/ S0301479713006543.]

Downard, R., J. Endter-Wada, and K. M. Kettenring (2014), Adaptive wetland management in an uncertain and changing arid environment, Ecol. Soc., 19(2), 23, doi:10.5751/ES-06412-190223. [Available at http://www.ecologyandsociety.org/vol19/iss2/art23/.]

Draper, A. (2001), Implicit stochastic optimization with limited foresight for reservoir systems, Doctoral thesis, Univ. of Calif. Davis, Davis, Calif. [Available at https://watershed.ucdavis.edu/shed/lund/students/DraperDissertation.pdf.]

Draper, A., M. Jenkins, K. Kirby, J. Lund, and R. Howitt (2003), Economic-engineering optimization for California water management, J. Water Resour. Plann. Manage., 129(3), 155-164, doi:10.1061/(ASCE)0733-9496(2003)129:3(155).

Euliss, N. H., L. M. Smith, D. A. Wilcox, and B. A. Browne (2008), Linking ecosystem processes with wetland management goals: Charting a course for a sustainable future, Wetlands, 28(3), 553-562, doi:10.1672/07-154.1.

Grossmann, I. E., J. Viswanathan, A. Vecchietti, R. Raman, and E. Kalvelagen (2002), GAMS/DICOPT: A Discrete Continuous Optimization Package, GAMS Dev. Corp., Washington, D. C. [Available at https://www.math.ucdavis.edu/ deloera/MISC/BIBLIOTECA/trunk/gams-dicopt-adiscrete.pdf.]

Hardy, T. B. (2005), The Theory and Application of the Physical Habitat Simulation System (PHABSIM), Utah Water Res. Lab., Utah State Univ., Logan.

Hazelton, E. L. G., T. J. Mozdzer, D. Burdick, K. M. Kettenring, and D. Whigham (2014), Phragmites australis management in the United States: 40 years of methods and outcomes, AoB Plants, vol 6, plu001 pp. [Available at http://aobpla.oxfordjournals.org/content/early/2014/01/ 16/aobpla.plu001.abstract.]

Higgins, A. J., B. A. Bryan, I. C. Overton, K. Holland, R. E. Lester, D. King, M. Nolan, and J. D. Connor (2011), Integrated modelling of costeffective siting and operation of flow-control infrastructure for river ecosystem conservation, Water Resour. Res., 47, W05519, doi: 10.1029/2010WR009919.

Hof, J. G., and M. Bevers (2002), Spatial Optimization in Ecological Applications, 320 pp., Columbia Univ. Press, N. Y.

Kadlec, J. A., and S. E. Adair (1994), Evaluation of water requirements for the marshes of the Bear River Delta, book report, Utah State Univ., Logan.

Kaminski, M. R., G. A. Baldassarre, and A. T. Pearse (2006), Waterbird responses to hydrological management of wetlands reserve program habitats in New York, Wildlife Soc. Bull., 34(4), 921-926, doi:10.2193/0091-7648(2006)34[921:WRTHMO]2.0.CO;2.

Kettenring, K. M., and C. R. Adams (2011), Lessons learned from invasive plant control experiments: A systematic review and meta-analysis, J. Appl. Ecol., 48(4), 970-979, doi:10.1111/j.1365-2664.2011.01979.x.

Kettenring, K. M., and K. E. Mock (2012), Genetic diversity, reproductive mode, and dispersal differ between the cryptic invader, Phragmites australis, and its native conspecific, Biol. Invasions, 14(12), 2489-2504, doi:10.1007/s10530-012-0246-5.

Kettenring, K. M., M. K. McCormick, H. M. Baron, and D. F. Whigham (2011), Mechanisms of Phragmites australis invasion: Feedbacks among genetic diversity, nutrients, and sexual reproduction, J. Appl. Ecol., 48(5), 1305-1313, doi:10.1111/j.1365-2664.2011.02024.x.

Kettenring, K. M., S. de Blois, and D. P. Hauber (2012a), Moving from a regional to a continental perspective of Phragmites australis invasion in North America, AoB Plants, vol 2012, pls040 pp. [Available at http://aobpla.oxfordjournals.org/content/2012/pls040.abstract.]

Kettenring, K. M., K. Garvie, E. L. Hazelton, E. L. Hough-Snee, and Z. Ma (2012b), Phragmites invasion and control in the Great Salt Lake watershed: 2012 land manager survey, Utah Dep. of Nat. Resour., Div. of For., Fire \& State Lands, Salt Lake City, Utah. [Available at https://works.bepress.com/karin kettenring/75/.]

Kettenring, K. M., D. F. Whigham, E. L. G. Hazelton, S. K. Gallagher, and H. M. Weiner (2015a), Biotic resistance, disturbance, and mode of colonization impact the invasion of a widespread, introduced wetland grass, Ecol. Appl., 25(2), 466-480, doi:10.1890/14-0434.1. 
Kettenring, K. M., C. B. Rohal, C. Cranney, D. England, and E. L. G. Hazelton (2015b), Treatments for effective restoration of Phragmites-dominated wetlands in the Great Salt Lake, 17 pp., Delta Waterfowl, Salt Lake City, Utah.

Kettenring, K. M., K. E. Mock, B. Zaman, and M. McKee (2016), Life on the edge: Reproductive mode and rate of invasive Phragmites australis patch expansion, Biol. Invasions, 18(9), 2475-2495, doi:10.1007/s10530-016-1125-2.

King, J. M., R. E. Tharme, and M. De Villiers (2008), Environmental flow assessments for rivers: Manual for the Building Block Methodology, Rep. TT 354/08, Water Res. Comm., Pretoria.

Langsdale, S., A. Beall, E. Bourget, E. Hagen, S. Kudlas, R. Palmer, D. Tate, and W. Werick (2013), Collaborative modeling for decision support in water resources: Principles and best practices, J. Am. Water Resour. Assoc., 49(3), 629-638, doi:10.1111/jawr.12065.

Loucks, D. P. (2006), Modeling and managing the interactions between hydrology, ecology and economics, J. Hydrol., 328(3-4), 408-416. [Available at http://www.sciencedirect.com/science/article/pii/S0022169405006451.]

Loucks, D. P., E. van Beek, J. R. Stedinger, J. P. M. Dijkman, and M. T. Villars (2005), Water Resources Systems Planning and Management: An Introduction to Methods, Models and Applications, The United Nations Educational Scientific and Cultural Organization (UNESCO), Paris. [Available at http://ecommons.library.cornell.edu/handle/1813/2804.]

Ma, Z., Y. Cai, B. Li, and J. Chen (2010), Managing wetland habitats for waterbirds: An international perspective, Wetlands, 30(1), 15-27, doi: 10.1007/s13157-009-0001-6.

Mitsch, W. J., and J. G. Gosselink (2007), Wetlands, 4th ed., John Wiley, Hoboken, N. J.

NISC (2003), General Guidelines for the Establishment and Evaluation of Invasive Species Early Detection and Rapid Response Systems, Washington, D. C.

Olson, B. E. (2007), Phragmites Control Plan, Bear River Migratory Bird Refuge, report, U.S. Fish and Wildlife Serv., Brigham City, Utah. [Available at https://github.com/alminagorta/Systems-model-in-Wetlands-to-Allocate-water-and-Manage-Plant-Spread/blob/master/4.SupplementaryDocumentation/Phragmites\%20Control\%20Plan.pdf.]

Olson, B. E., K. Lindsey, and V. Hirschboeck (2004), Habitat Management Plan, Bear River Migratory Bird Refuge, report, U.S. Fish and Wildlife Serv., Brigham City, Utah. [Available at https://github.com/alminagorta/Systems-model-in-Wetlands-to-Allocate-water-and-ManagePlant-Spread/blob/master/4.SupplementaryDocumentation/Habitat\%20Management\%20Plan.pdf.]

Payne, T. R. (2003), The concept of weighted usable area as relative suitability index, Paper presented at the International IFIM User's Workshop, June 1-5 2003 at Colorado State University, Fort Collins, Colo.

Rickey, M. A., and R. C. Anderson (2004), Effects of nitrogen addition on the invasive grass Phragmites australis and a native competitor Spartina pectinata, J. Appl. Ecol., 41(5), 888-896, doi:10.1111/j.0021-8901.2004.00948.x.

Rosenthal, R. E. (2014), GAMS--A user's guide, report, 304 pp., GAMS Dev. Corp., Washington, D. C. [Available at http://www.gams.com.]

Saltonstall, K. (2002), Cryptic invasion by a non-native genotype of the common reed, Phragmites australis, into North America, Proc. Natl. Acad. Sci. U. S. A., 99(4), 2445.

Stannard, D. I., M. W. Gannett, D. J. Polette, J. M. Cameron, M. S. Waibel, and J. M. Spears (2013), Evapotranspiration from Wetland and Open-Water Sites at Upper Klamath Lake, Oregon, 2008-2010, report number 2013-5014, 66 pp., U.S. Geol. Surv. Sci. Invest., Reston, Va. [Available at http://pubs.usgs.gov/sir/2013/5014/pdf/sir20135014.pdf.]

Steinschneider, S., A. Bernstein, R. Palmer, and A. Polebitski (2013), Reservoir management optimization for basin-wide ecological restoration in the Connecticut River, J. Water Resour. Plann. Manage., 140(9), 04014023, doi:10.1061/(ASCE)WR.1943-5452.0000399.

Stralberg, D., D. L. Applegate, S. J. Phillips, M. P. Herzog, N. Nur, and N. Warnock (2009), Optimizing wetland restoration and management for avian communities using a mixed integer programming approach, Biol. Conserv., 142(1), 94-109. [Available at http://www.sciencedirect.com/science/article/B6V5X-4V1D7S9-1/2/569a189e44409448d8f169d1199b52a1.]

Szemis, J. M., H. R. Maier, and G. C. Dandy (2014), An adaptive ant colony optimization framework for scheduling environmental flow management alternatives under varied environmental water availability conditions, Water Resour. Res., 50, 7606-7625, doi:10.1002/ 2013 WR015187.

Tarboton, K. C., M. M. Irizarry-Ortiz, D. P. Loucks, S. M. Davis, and J. T. Obeysekera (2004), Habitat suitability indices for evaluating water management alternatives, office of modeling technical report, South Fla. Water Manage. Dist., West Palm Beach.

Vanderlinder, M. S., C. M. U. Neale, D. E. Rosenberg, and K. M. Kettenring (2014), Use of remote sensing to assess changes in wetland plant communities over an 18-year period: A case study from the Bear River Migratory Bird Refuge, Great Salt Lake, Utah, West. North Am. Nat., 74(1), 33-46, doi:10.3398/064.074.0104.

Vogel, R. M., J. Sieber, S. A. Archfield, M. P. Smith, C. D. Apse, and A. Huber-Lee (2007), Relations among storage, yield, and instream flow, Water Resour. Res., 43, W05403, doi:10.1029/2006WR005226.

Waddle, T. J. (2001), PHABSIM for Windows: User's Manual and Exercises, 288 pp., U.S. Geol. Surv., Fort Collins, Colo. [Available at http://www. fort.usgs.gov/products/Publications/15000/preface.html]

Weisner, S. E. B., and J. A. Strand (1996), Rhizome Architecture in Phragmites Australis in Relation to Water Depth: Implications for WithinPlant Oxygen Transport Distances, Folia Geobotanica Phytotaxonomica, 31(1), 91-97. [Available at http://www.jstor.org/stable/4181420.]

Wurtsbaugh, W., C. Miller, S. Null, P. Wilcock, M. Hahnenberger, and F. Howe (2016), Impacts of Water Development on Great Salt Lake and the Wasatch Front, Watershed Sciences Faculty Publications, Paper 875, Utah State University, Logan, Utah. [Available at http://digitalcommons.usu.edu/wats_facpub/875/.]

Zedler, J. B., and S. Kercher (2004), Causes and consequences of invasive plants in wetlands: Opportunities, opportunists, and outcomes, Critical Rev. Plant Sci., 23(5), 431-452, doi:10.1080/07352680490514673.

Zedler, J. B., and S. Kercher (2005), Wetland resources: Status, trends, ecosystem services, and restorability, in Annual Review of Environment and Resources, pp. 39-74, Annual Reviews, Palo Alto, Calif. [Available at http://www.annualreviews.org/doi/abs/10.1146/annurev.energy. 30.050504.144248.] 